\title{
RELATIONSHIP BETWEEN cagA-POSITIVE Helicobacter pylori INFECTION AND RISK OF GASTRIC CANCER: a case control study in Porto Alegre, RS, Brazil
}

\author{
Gilmara Coelho MEINE${ }^{1}$, Cláudia ROTA², Judite DIETZ ${ }^{3}$, Setsuo SEKINE³ and João Carlos PROLLA ${ }^{1}$
}

\begin{abstract}
Context - Gastric cancer is the second most common cause of cancer related death worldwide. Although Helicobacter pylori has been classified as a class I carcinogen, the presence of infection is not a factor that alone is able to lead to gastric cancer, and one of the possible explanations for this is the existence of different strains of $H$. pylori with different degrees of virulence. Objectives - To investigate the association between cagA-positive H. pylori and gastric cancer, using polymerase chain reaction (PCR) for the detection of this bacterial strain. Methods - Twenty-nine patients with gastric cancer were matched by sex and age ( \pm 5 years) with 58 patients without gastric cancer, submitted to upper gastrointestinal endoscopy. All patients were evaluated for the status of infection by H. pylori (through urease test, histological analysis and PCR for the genes ure A and 16SrRNA) and by cagA-positive strain (through PCR for cagA gene). Results - Evaluating the presence of infection by cagA-positive H. pylori, it was verified that the rate of infection was significantly higher in the group with gastric cancer when compared with the matched controls, occurring in $62.1 \%$ and $29.3 \%$, respectively (OR $=3.95$; CI 95\% 1.543-10.096). Conclusions - There is an association between cagA-positive H. pylori strain and risk of gastric cancer.
\end{abstract}

HEADINGS - Helicobacter pylori. Helicobacter infections. cagA protein, Helicobacter pylori., Stomach neoplasms.

\section{INTRODUCTION}

Gastric cancer is the fourth more frequent neoplasm and the second most common cause of cancer related death worldwide ${ }^{(26)}$, despite the decrease in the incidence in the last decades ${ }^{(12)}$.

The process of gastric carcinogenesis is not yet completely understood, but environmental risk factors identified for the development of this neoplasm are: diet rich in salt and preserved foods ( $\mathrm{N}$-nitroso compounds) $)^{(10,37)}$ and poor in anti-oxidants, such as vitamin $\mathrm{A}$ and $\mathrm{C}^{(2,10,29)}$, tobacco smoking ${ }^{(10,17)}$ and infection by Helicobacter pylori ${ }^{(6,10,15,23,35)}$.

H. pylori was first isolated in 1982 by Warren and Marshall ${ }^{(39)}$, and once its identification, this bacteria promptly became the target of several studies. In 1994, the World Health Organization and the International Agency for Research on Cancer determined that there was sufficient evidence in humans for the carcinogenicity of infection with $H$. pylori, classifying this bacteria as a class I carcinogen ${ }^{(15)}$.

H. pylori infection is one of the most common in the human species. In different countries, the prevalence rate of infection may vary from $30 \%$ to $90 \%{ }^{(4)}$, depending mainly of the age and the social-economic level.
According to meta-analyzes about the relationship between soropositivity to $H$. pylori and gastric cancer, the odds ratio for infected patients is about $1.92^{(14)}$.

Uemura et al. ${ }^{(38)}$ and Hsu et al. ${ }^{(13)}$, in prospective cohort studies of 7.8 and 6.3-year follow-up, found that gastric cancer developed, respectively, in $2.9 \%$ and $1,1 \%$ of those who were $H$. pylori-positive, compared with none of those who were not infected.

Perhaps, the presence of the infection is not a factor that alone is able to lead to gastric cancer, as not all individuals who are infected will develop the neoplasm and the rates of gastric cancer are low in some countries were the rates of $H$. pylori infection are high ${ }^{(33)}$. Possible explanations for these findings are: differences in host genetics, other associated environmental factors and the existence of different strains of $H$. pylori with different degrees of virulence ${ }^{(9)}$.

H. pylori may cause damage to the gastric epithelial cell by mechanisms related to pathogenic factors of the bacteria, mainly by the proteins coded by the genes vac $\mathrm{A}, c a g \mathrm{~A}, i c e \mathrm{~A}$ and $b a b \mathrm{~A}^{(21)}$.

H. pylori cagA-positive strains have been associated with gastric ulcer ${ }^{(7,25)}$, duodenal ulcer ${ }^{(7,30)}$ and gastric cancer $^{(1,7,8,28,31)}$.

Postgraduation Program in Gastroenterology, Universidade Federal do Rio Grande do Sul; ${ }^{2}$ Amplicon - Laboratory of Molecular and Cellular Biology; ${ }^{3}$ Department of Endoscopy, Hospital Nossa Senhora da Conceição, Porto Alegre, RS, Brasil.

Correspondence: Dr. Gilmara Coelho Meine - Av. Dr. Maurício Cardoso, 833/409 - 93510-250 - Novo Hamburgo, RS, Brasil. E-mail: gilmeine@terra.com.br 
Approximately $60 \%-80 \%$ of $\mathrm{H}$. pylori strains express a high molecular weight protein, denominated CagA, coded by the cagA gene. CagA protein is translocated into the intracellular region of gastric epithelial cell, allowing the bacteria to modulate pathways of the cellular metabolism of the host ${ }^{(5,}$ ${ }^{11)}$, inducing cellular hyper proliferation ${ }^{(19)}$, apoptosis ${ }^{(22)}$ and leading to failure of gastric epithelial cell ability to maintain its normal cytoskeletal structure, an important prerequisite for neoplastic transformation ${ }^{(32)}$. Also, induce interleukin-8 (IL-8) production by the epithelial cells. The IL-8 leads to intense inflammatory response and production of oxygen free radicals that could cause DNA damage to adjacent cells. Accumulation of oxidative DNA damage could lead to genetic modifications of gastric epithelial cells that are carcinogenic $^{(21)}$.

The present study has the objective of investigating the association between cagA-positive H. pylori and gastric cancer, using polymerase chain reaction (PCR) for the detection of this bacterial strain.

\section{METHODS}

This study was approved by the Ethics Committee of the Hospital Nossa Senhora da Conceição, Porto Alegre, RS, Brazil.

Considering cagA-positive $H$. pylori infection prevalence of $64 \%$ in patients with gastric cancer and $30 \%$ in patients without this neoplasia, with confidence interval $95 \%$, power $80 \%$ and case: control rate $1: 2$, the minimum sample size required to evaluate the relationship between cagA-positive H. pylori infection and risk of gastric cancer was 29 patients in the case group and 58 patients in the control group.

From August 2003 to December 2004 were studied prospectively 29 patients with gastric cancer, and they were matched by sex and age ( \pm 5 years) with 58 patients without gastric cancer, all evaluated through upper gastrointestinal endoscopy at Hospital Nossa Senhora da Conceição.

The inclusion criteria for the case group were: histopathological diagnosis of gastric adenocarcinoma through biopsies obtained during endoscopic exam, age 18 years or older and consent to participate. The exclusion criteria were: upper gastrointestinal hemorrhage, therapy with antibiotics within the last 6 months, history of subtotal gastrectomy and diagnosis of gastric cancer established more than 6 months previously.

The inclusion criteria for the matched control group were: patients submitted to upper gastrointestinal endoscopy in which the diagnosis was not gastric cancer, age 18 years or older and consent to participate. The exclusion criteria were: upper gastrointestinal hemorrhage, therapy with antibiotics within the last 6 months and history of subtotal gastrectomy.

During endoscopy, were collected biopsies of gastric corpus, incisura angularis and antrum of all cases and controls patients. The gastric biopsies of all patients were evaluated for the detection of $H$. pylori (through 3 methods: urease test, histological analysis and PCR for the genes ure A and 16SrRNA) and the cagA gene (through PCR for the gene
cagA). Patients in whom the genes ure A and 16SrRNA were detected by PCR and/or two other methods for detection of $H$. pylori were positive were considered $H$. pylori-positive. Patients in whom the gene $\operatorname{cagA}$ was detected by PCR were considered cagA-positive.

\section{Urease test}

Carried out through one antrum and one corpus biopsies.

\section{Histological analysis}

Carried out through two antrum, one incisura angularis and two corpus biopsies. Sections were stained with $\mathrm{H}-\mathrm{E}$ to grade the severity of gastritis and to evaluate the presence of atrophy and intestinal metaplasia, and with Giemsa to detect H. pylori.

\section{Preparation of DNA for PCR amplification}

The biopsy specimens for DNA analysis were placed in $0.9 \% \mathrm{NaCl}$, and the DNA was isolated directly from the biopsy specimens using the QIAamp tissue kit (QIAgen Inc., Santa Clarita, Calif, USA.).

\section{H. pylori and cagA detection by PCR}

One gastric biopsy specimen from the antrum was subjected to PCR, targing the ureA, 16SrRNA and cagA gene detection, using sets of synthetic oligonucleotides primers, as described elsewhere by Rota et al. ${ }^{(30)}$. The primers HPU18N (5'-CCCATTTGACTCAATGCGATG-3') and HPU54N (5'TGGGATTAGCGAGTATGTCGG-3') were used to amplify a 132-bp product from the $16 \mathrm{Sr} R N A$ gene, and the primers UREA1 (5'-GCCAATGGTAAATTAGTT-3') and UREA2 (5'CTCCTTAATTGTTTTTAC-3') were used to amplify a 394-bp product from the ure $\mathrm{A}$ gene. The forward and reverse primers CagA/ConF (5'-GTGCCTGCTAGTTTGTCAGCG-3') and CagA/Con-R (5'-TTGGAAACCACCTTTTGTATTAGC-3') were used to amplify a 402-bp fragment of the cagA gene (Figure 1).

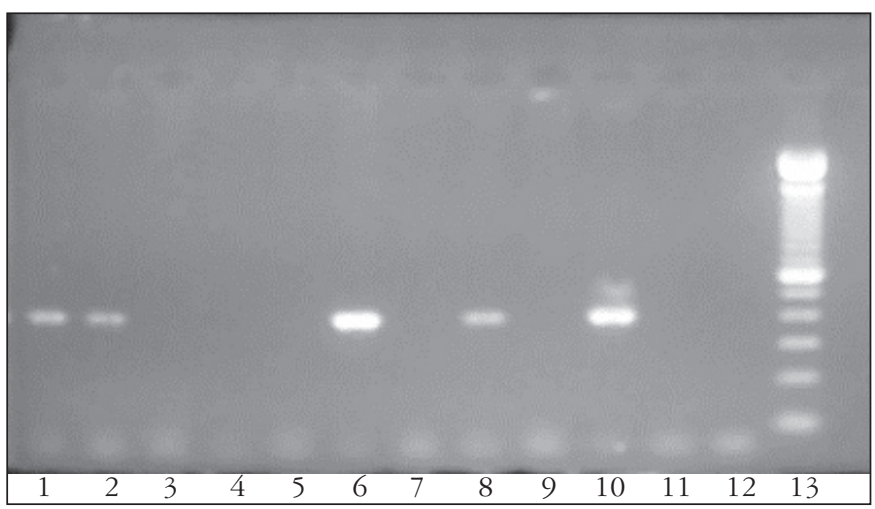

FIGURE 1. PCR amplification of cag $A$ gene: lanes 1, 2, 6 and 8: positive PCR products; lanes 3, 4, 5, 7 and 9: negative PCR products; lane 10: positive control; lanes 11 and 12: negative control (without DNA); lane 13: molecular weight marker 
Meine GC, Rota C, Dietz J, Sekine S, Prolla JC. Relationship between cagA-positive Helicobacter pylori infection and risk of gastric cancer: a case control study in Porto Alegre, RS, Brazil

For statistical analysis, categorical variables were evaluated through $\mathrm{x}^{2}$ test, Fischer exact or Yates correction. Significance was defined as $P$ values $<0.05$. Continual variables were evaluated through Student $t$ test. Odds ratio was used as association measure.

\section{RESULTS}

The characteristics of the 29 patients with gastric adenocarcinoma and the 58 matched controls are described in Table 1.

Case group - all patients presented with non-cardia gastric adenocarcinoma. While among men the most frequent histological classification was intestinal type adenocarcinoma $(66.7 \%)$, among women, it was diffuse type adenocarcinoma $(54.5 \%)(P=0.039)$. Atrophy and/or gastric intestinal metaplasia were identified through histological analysis of biopsy samples from gastric segments without cancer in $65.5 \%$ of the patients.

Control group - the endoscopic findings were: normal exam (11 patients), enantematous gastritis (14 patients), erosive gastritis (13 patients), erosive duodenitis (5 patients), gastric ulcer (11 patients) and duodenal ulcer (4 patients). Atrophy and/or gastric intestinal metaplasia were identified through histological analysis of gastric biopsy samples in $32.7 \%$ of the patients, and were more frequent in cagA-positive $H$. pylori patients, however, the result did not achieve statistical significance $(\mathrm{OR}=2.42$, CI 95\% 0.76-7.70).

Case vs control group - cagA-positive $H$. pylori infection prevalence was significantly higher in the case group, when compared with the control group, occurring in $62.1 \%$ and $29.3 \%$, respectively $(\mathrm{OR}=3.95$; CI 95\% 1.54-10.09) (Table 2).

Considering only $H$. pylori-positive patients, there was stronger relationship between cagA-positive strain and gastric cancer. The frequency of cagA-positive infection in the case group was $90 \%$ compared with $42.5 \%$ in the control group $(\mathrm{OR}=12.18 ;$ CI 95\% 2.71-52.9) $($ Table 2$)$.

\section{DISCUSSION}

Despite H. pylori colonizes the stomach of about half of the world population, only $1 \%-2 \%$ of the infected individuals will evolve to gastric cancer. Among the possible explanations is the fact that specific $H$. pylori genotypes have been associated to more virulent presentations.
TABLE 2. Risk of distal gastric adenocarcinoma according to status of infection by Helicobacter pylori cagA + strain

\begin{tabular}{lccccc}
\hline & $\begin{array}{c}\text { Cancer } \\
\text { patients }\end{array}$ & \multicolumn{2}{c}{$\begin{array}{c}\text { Matched } \\
\text { controls }\end{array}$} \\
\hline & $c a g A+$ & $c a g A-$ & $c a g A+$ & $c a g A-$ & OR (CI 95\%) \\
All patients & 18 & 11 & 17 & 41 & $3,95(1,54-10,09)$ \\
H. pylori + patients & 18 & 2 & 17 & 23 & $12,18(2,71-52,9)$ \\
\hline
\end{tabular}

Several case-control studies, in different countries, have investigated the association between cagA-positive $H$. pylori and gastric cancer, and most evidence in literature agrees this association does exist ${ }^{(3,6,16,18,20,27,28,34)}$.

Considering the known difference in the populational characteristics among the different countries and the fact that no study about this association has been previously carried out in south of Brazil, it becomes relevant to know the results obtained in our region.

The same rate of infection by $H$. pylori was identified in case and control groups. Possible reasons are: a) the sample size was not calculated to evaluate the relationship between $H$. pylori infection and gastric cancer, b) patients with gastric and duodenal ulcers (diseases also related to $H$. pylori infection) were included in the control group, and c) the fact that all patients in the case group presented with advanced cancer, and a significant parcel of these loose the colonization by $H$. pylori in the evolution of the disease ${ }^{(24)}$, since the neoplastic tissue, as well as gastric epithelium severely atrophic and with intestinal metaplasia, are not the adequate habitat for development of this bacteria. Ekström et al. ${ }^{(6)}$ describe that loss of infection may precede a cancer diagnosis by decades, and in these conditions the rate of $H$. pylori exposure may be underestimated.

The present study demonstrates that cagA-positive $H$. pylori is associated significantly with non-cardia gastric cancer $(\mathrm{OR}=3.95$; CI 95\% 1.543-10.096). However, a stronger association between cagA-positive $\mathrm{H}$. pylori and gastric cancer was identified when we compared only $H$. pylori-positive patients of both groups (OR = 12.18; CI 95\% 2.71-52.9). Demonstrating that, in our region, once we identify the infection by $\mathrm{H}$. pylori, $90 \%$ of gastric cancer patients present infection by cagA-positive strain.

In the future, studies evaluating the relationship between cagA-positive $H$. pylori strains and gastric cancer should associate the use of PCR for cagA gene and serology for CagA

TABLE 1. Characteristics of case and matched-control groups

\begin{tabular}{lccccc}
\hline & $\mathrm{n}$ & Male $\mathrm{n}(\%)$ & Mean age & H. pylori+n $(\%)$ & cag $+\mathrm{n}(\%)$ \\
\hline Non-cardia gastric cancer & 29 & $18(62,1 \%)$ & 65,8 & $20(68,9 \%)$ & $18(62,1 \%)$ \\
$\quad$ Intestinal & 16 & $12(75 \%)$ & 67,1 & $10(62,5 \%)$ & $9(56,2 \%)$ \\
Diffuse & 8 & $2(25 \%)$ & 56,5 & $6(75 \%)$ & $5(62,5 \%)$ \\
Indeterminated & 5 & $4(80 \%)$ & 76,6 & $4(80 \%)$ & $4(80 \%)$ \\
Matched-control & 58 & $36(62,1 \%)$ & 64,1 & $40(68,9 \%)$ & $17(29,3 \%)$ \\
Normal exam or enantematous gastritis & 25 & $16(64 \%)$ & 66,8 & $17(68 \%)$ & $9(36 \%)$ \\
Erosive gastritis and/or duodenitis & 18 & $10(55,5 \%)$ & 59,8 & $11(61,1 \%)$ & $2(11,1 \%)$ \\
Peptic ulcer & 15 & $10(66,7 \%)$ & 64,7 & $12(80 \%)$ & $6(40 \%)$ \\
\hline
\end{tabular}


antigen in an attempt to identify not only patients with actual infection by cagA-positive H. pylori (situation in which PCR presents elevated sensibility), but also patients that presented infection by this strain in a recent past of up to 32 months (situation which can be detected only by serology) ${ }^{(36)}$.

\section{CONCLUSIONS}

We conclude that exists an association between cagApositive $H$. pylori infection and distal gastric cancer in Porto Alegre, Brazil (OR = 3.947; CI 1.543-10.096). The behavior of the infection by this bacterial strain strengths the hypothesis that it plays an important rule in the pathogenesis of gastric cancer. Thus, we might consider the possibility that the cagA-positive $H$. pylori infection can be a marker for individuals at an increased risk for the development of non-cardia gastric cancer.

Nevertheless, to suggest a change in the management of $H$. pylori infected patients, it is necessary the accomplishment of additional long term prospective studies, evaluating the impact of the eradication of cagA-positive strain infection on the risk of development of gastric cancer.

Meine GC, Rota C, Dietz J, Sekine S, Prolla JC. Relação entre infecção por Helicobacter pylori linhagem cagA-positiva e risco de câncer gástrico: um estudo caso-controle em Porto Alegre, Brasil. Arq Gastroenterol. 2011;48(1):41-5.

RESUMO - Contexto - O câncer gástrico é a segunda causa mais comum de mortes relacionadas à neoplasia em todo o mundo. Embora o Helicobacter pylori seja classificado como um carcinógeno classe I, a presença da infecção não é um fator que isoladamente possa conduzir ao câncer gástrico e, uma das possíveis justificativas, é a existência de diferentes linhagens de H. pylori com diferentes graus de virulência. Objetivo - Investigar a associação entre H. pylori cagA-positivo e câncer gástrico, utilizando a reação em cadeia de polimerase (PCR) para a detecção desta linhagem bacteriana. Métodos - Vinte e nove pacientes com câncer gástrico foram pareados por sexo e por idade ( \pm 5 anos) com 58 pacientes sem câncer gástrico, submetidos a endoscopia digestiva alta. Todos os pacientes foram avaliados quanto à presença de infecção pelo H. pylori (com teste da urease, análise histológica e PCR para os genes ureA e 16SrRNA) e pela linhagem cagA desta bactéria (com PCR para o gene cagA). Resultados - Avaliando a presença de infecção por $H$. pylori cagA-positivo, verificou-se que a taxa da infecção era significativamente mais alta no grupo de pacientes com câncer gástrico, quando comparado com o grupo controle, ocorrendo em $62,1 \%$ e em $29,3 \%$, respectivamente (OR = 3,95; CI 95\% 1,543-10,096). Conclusões - Há associação entre H. pylori cagA-positivo e risco de câncer gástrico.

DESCRITORES - Helicobacter pylori. Infecções por helicobacter. cagA proteína, Helicobacter pylori. Neoplasias gástricas.

\section{REFERENCES}

1. Ashour AA, Magalhães PP, Mendes EN, Collares GB, de Gusmão VR, Queiroz DM, Nogueira AM, Rocha GA, de Oliveira CA. Distribution of vacA genotypes in Helicobacter pylori strains isolated from Brazilian adult patients with gastritis, duodenal ulcer or gastric carcinoma. FEMS Immunol Med Microbiol. 2002;33:173-8

2. Bartsch $\mathrm{H}, \mathrm{Ohshima} \mathrm{H}$, Pignatelli B. Inhibitors of endogenous nitrosation mechanisms and implications in human cancer prevention. Mutat Res. 1988;202:307-24.

3. Brenner H, Arndt V, Stürmer T, Stegmaier C, Ziegler H, Dhom G. Individual and joint contribution of family history and Helicobacter pylori infection to the risk of gastric carcinoma. Cancer. 2000;88:274-9.

4. Coelho LG, León-Barúa R, Quigley EM. Latin-American consensus conference on Helicobacter pylori infection. Latin-American National Gastroenterological Societies affiliated with the Inter-American Association of Gastroenterology (AIGE). Am J Gastroenterol. 2000;95:2688-91.

5. Covacci A, Telford JL, Del Giudice G, Parsonnet J, Rappuoli R. Helicobacter pylori virulence and genetic geography [review]. Science. 1999;284:1328-33.

6. Ekström AM, Held M, Hansson LE, Engstrand L, Nyrén O. Helicobacter pylori in gastric cancer established by $\operatorname{Cag} A$ immunoblot as a marker of past infection. Gastroenterology. 2001;121:784-91.

7. Figueiredo C, Van Doorn LJ, Nogueira C, Soares JM, Pinho C, Figueira P, Quint WG, Carneiro F. Helicobacter pylori genotypes are associated with clinical outcome in Portuguese patients and show a high prevalence of infections with multiple strains. Scand J Gastroenterol. 2001;36:128-35.

8. Figueiredo C, Machado JC, Pharoah P, Seruca R, Sousa S, Carvalho R, Capelinha AF, Quint W, Caldas C, van Doorn LJ, Carneiro F, Sobrinho-Simoes M. Helicobacter pylori and interleukin 1 genotyping: an opportunity to identify high-risk individuals for gastric carcinoma. J Natl Cancer Inst. 2002;94:1680-7.

9. Forbes GM, Threlfall TJ. Treatment of Helicobacter pylori infection to reduce gastric cancer incidence: uncertain benefits of a community based program in Australia. J Gastroenterol Hepatol. 1998;13:1091-5.
10. Goh KL, Cheah PL, Md N, Quek KF, Parasakthi N. Ethnicity and Helicobacter pylori as risk factors for gastric cancer in Malaysia: a prospective case control study. Am J Gastroenterol. 2007;102:40-5.

11. Guo XL, Yuan Y, Du SY, Fan CL, Wang LE, Li L, Wang P. Association of cyclooxygenase-2 expression with $H p$-cagA infection in gastric cancer. World J Gastroenterol. 2003;9:246-9.

12. Howson CP, Hiyama T, Wynder EL. The decline in gastric cancer: epidemiology of an unplanned triumph. Epidemiol Rev. 1986;8:1-27.

13. Hsu PI, Lai KH, Hsu PN, Lo GH, Yu HC, Chen WC, Tsay FW, Lin HC, Tseng $\mathrm{HH}$, Ger LP, Chen HC. Helicobacter pylori infection and the risk of gastric malignancy. Am J Gastroenterol. 2007;102:725-30.

14. Huang JQ, Sridhar S, Chen Y, Hunt RH. Meta-analysis of the relationship between Helicobacter pylori seropositivity and gastric cancer. Gastroenterology. 1998:114:1169-79.

15. IARC Working Group on the Evaluation of Carcinogenic Risks to Humans. Schistosomoses, liver flukes and Helicobacter pylori. Lyon, France; 1994. (IARC monographs on the evaluation of carcinogenic risks to humans, v.61) 270p. Avaliable at: http://monographs.iarc.fr/ENG/Monographs/vol61/index.php

16. Kikuchi S, Crabtree JE, Forman D, Kurosawa M. Association between infections with CagA-positive or-negative strains of Helicobacter pylori and risk for gastric cancer in young adults. Research group on prevention of gastric carcinoma among young adults. Am J Gastroenterol. 1999;94:3455-9.

17. Kneller RW, Mclaughlin JK, Bjelke E, Schuman LM, Blot WJ, Wacholder S, Gridley G, CoChien HT, Fraumeni JF Jr. A cohort study of stomach cancer in a high risk American population. Cancer. 1991;68:672-8.

18. Konturek SJ, Starzynska T, Konturek PC, Karczewska E, Marlicz K, Lawniczak M, Jaroszewicz-Heigelman H, Bielanski W, Hartwich A, Ziemniak A, Hahn EG. Helicobacter pylori and $\operatorname{cag} A$ status, serum gastrin, interleukin- 8 and gastric acid secretion in gastric cancer. Scand J Gastroenterol. 2002;37:891-8.

19. Leite KR, Darini E, Canavez F, Carvalho CM, Mitteldorf CATS, Camara-Lopes LH. Helicobacter pylori and cag A gene detected by polymerase chain reaction in gastric biopsies: correlation with histological findings, proliferation and apoptosis. São Paulo Med J. 2005;123:113-8. 
20. Maeda S, Yoshida H, Ogura K, Yamaji Y, Ikenoue T, Mitsushima T, Tagawa H, Kawagushi R, Mori K, Mafune K, Kawabe T, Shiratori Y, Omata M. Assessment of gastric carcinoma risk associated with Helicobacter pylori may vary depending on the antigen used: $\operatorname{Cag} A$ specific enzyme-linked immunosorbent assay (ELISA) versus commercialy available $H$. pylori ELISAs. Cancer. 2000;88:1530-5.

21. Marshall BJ. Helicobacter pylori: 20 years on. Clin Med. 2002;2:147-52.

22. Minohara Y, Boyd D, Hawkins HK, Ernst PB, Patel J, Crowe SE. The effect of the cag pathogenicity island on binding of Helicobacter pylori to gastric epithelial cells and the subsequent induction of apoptosis. Helicobacter. 2007;12:583-90.

23. Nogueira AM, Ribeiro GM, Rodrigues MA, Queiroz DM, Mendes EN, Rocha GA, Barbosa AJ. Prevalence of Helicobacter pylori in Brazilian patients with gastric carcinoma. Am J Clin Pathol. 1993;100:236-9.

24. Nomura A, Stemmermann GN, Chyou PH, Kato I, Perez-Perez GI, Blazer MJ. Helicobacter pylori infection and gastric carcinoma among Japanese Americans in Hawaii. N Engl J Med. 1991;325:1132-6.

25. Nomura AM, Pérez-Pérez GI, Lee J, Stemmermann G, Blaser MJ. Relation between Helicobacter pylori cag $A$ status and risk o peptic ulcer disease. Am J Epidemiol. 2002;155:1054-9.

26. Parkin DM, Bray FI, Devesa SS. Cancer Burden in the year 2000. The global picture. Eur J Cancer 2001;37:s4-66.

27. Parsonnet J, Friedman GD, Orentreich N, Vogelman H. Risk for gastric cancer in people with $\operatorname{Cag} A$ positive or $\operatorname{Cag} A$ negative Helicobacter pylori infection. Gut. 1997;40:297-301.

28. Queiroz DM, Mendes EN, Rocha GA, Oliveira AM, Oliveira CA, Magalhães PP, Moura SB, Cabral MM, Nogueira AM. cagA-positive Helicobacter pylori and risk for developing gastric carcinoma in Brazil. Int J Cancer. 1998;78:135-9.

29. Risch HA, Jain M, Choi NW, Fodor JG, Pfeiffer CJ, Howe GR, Harrison LW, Craib KJ, Miller AB. Dietary factors and the incidence of cancer of the stomach. Am J Epidemiol. 1985;122:947-59.

30. Rota CA, Pereira-Lima JC, Blaya C, Nardi NB. Consensus and variable region PCR analysis of Helicobacter pylori 3' region of cagA gene in isolates from individuals with or without peptic ulcer. J Clin Microbiol. 2001;39:606-12.
31. Saruç M, Demir MA, Küçükmetin N, Kandiloglu AR, Akarca US, Yüceyar $\mathrm{H}$. Histological and clinic predictive value of determination of tissue $\operatorname{Cag} A$ status by PCR in Helicobacter pylori infected patients; results of the large population based study in western Turkey. Hepatogastroenterology. 2002;49: 878-81.

32. Segal ED, Cha J, Lo J, Falkov F, Tompkins LS. Altered states: involvement of phosphorylated $\operatorname{Cag} A$ in the induction of host cellular growth changes by Helicobacter pylori. Proc Natl Acad Sci USA. 1999;96:14559-64.

33. Segal I, Ally R, Mitchell H. Gastric cancer in sub-Saharan Africa. Eur J Cancer Prev. 2001;10:479-82

34. Shimoyama T, Fukuda S, Tanaka M, Mikami T, Munakata A, Crabtree JE. $\operatorname{Cag} A$ seropositivity associated with development of gastric cancer in a Japanese population. Clin Pathol. 1998;51:225-8.

35. Sipponen P, Hyvärinen H. Role of Helicobacter pylori in the pathogenesis of gastritis, peptic ulcer and gastric cancer. Scand J Gastroenterol. 1993;196: 3-6.

36. Sörberg M, Engstrand L, Ström M, Jonsson KA, Jorbeck H, Granström M. The diagnostic value of enzyme immunoassay and immunoblot in monitoring eradication of Helicobacter pylori. Scand J Infect Dis. 1997;29:147-51.

37. Takahashi M, Kokubo T, Furukawa F, Kurokawa Y, Hayashi Y. Effects of sodium chloride, saccharin, phenobarbital and aspirin on gastric carcinogenesis rats after inhibition with N-methyl-N-nitro-N-nitroso guanidine. Gann. 1984;75 494-501.

38. Uemura N, Okamoto S, Yamamoto S, Matsumura N, Yamaguchi S, Yamakido M, Taniyama K, Sasaki N, Schlemper RJ. Helicobacter pylori infection and the development of gastric cancer. N Engl J Med. 2001;345:784-9.

39. Warren JR, Marshall BJ. Unidentified curved bacilli in the stomach of patients with gastritis and peptic ulceration. Lancet. 1984;1:1311-15.

Received 20/5/2010

Accepted 6/8/2010 